\title{
Inferring palaeoecology in extinct tremarctine bears (Carnivora, Ursidae) using geometric morphometrics
}

\author{
BORJA FIGUEIRIDO AND LEOPOLDO H. SOIBELZON
}

\section{LETHAIA}

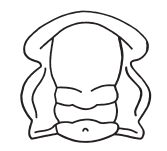

\begin{abstract}
Figueirido, B. \& Soibelzon, L.H. 2009: Inferring palaeoecology in extinct tremarctine bears (Carnivora, Ursidae) using geometric morphometrics. Lethaia, 10.1111/j.1502-3931.2009.00184.x.

In this study we explore the ecomorphological patterns of extinct tremarctine bears in South America during the Great American Biotic Interchange (GABI). These patterns are used to derive palaeoautoecological inferences in extinct tremarctines and their palaeosinecological relationships within Plio-Pleistocene ecosystems. We used geometric morphometrics of landmark data to recover the shape of the craniomandibular skeleton of bears. The results reveal different ecomorphological specializations in extinct tremarctines during the Plio-Pleistocene of South America. Indeed, these bears could have increased the percentage of plant matter in their diets according with the increased diversity of large carnivores in South America after the GABI. Omnivorous bears retain the ability to behave as carnivores or herbivores depending on resource availability. This fact strongly supports that bears are one of the most ecologically and morphologically adaptable members of the large carnivore guild. Moreover, their skull morphology could reflect ecological adaptations under different selection pressures with the required evolutionary time. $\square$ Evolution, GABI, geometric morphometrics, palaeoecology, Tremarctinae.
\end{abstract}

Borja Figueirido [francisco.figueirido@uv.es], Departamento de Ecología y Geología, Facultad de Ciencias, Universidad de Málaga, 29071 Málaga, Spain; Leopoldo H. Soibelzon [lsoibelzon@fcnym.unlp.edu.ar], Departamento Científico Palaeontología de Vertebrados, Museo de La Plata, Paseo del Bosque (1900), La Plata, Buenos Aires, Argentina; manuscript received on 19/03/2009; manuscript accepted on 05/05/2009.
The evolutionary history of bears (Mammalia, Carnivora, Ursidae) is strongly marked by a rapid adaptative radiation at the Mio-Pliocene boundary. Among bears this substantially increased diversity may be correlated with major global climate changes, which indicate a strong influence on bear evolution (Krause et al. 2008).

With this ecological scenario, the subfamily Tremarctinae (Carnivora, Ursidae) radiated in the New World, most probably from the Eurasian genus Ursavus (Thenius 1959, 1976; Kurtén 1966; McLellan \& Reiner 1994). The first tremarctines known in the fossil record are species of Plionarctos ( $P$. edensis and $P$. harroldorum), recorded from several Mio-Pliocene localities of North America (Tedford \& Martin 2001). Within the tremarctine phylogeny, Plionarctos is a paraphyletic stem-group from which more recent species of the Pleistocene emerged (Tedford \& Martin 2001). This was the case of North American shortfaced bears (Arctodus simus and Arctodus pristinus) and the extinct spectacled bear (Tremarctos floridanus), which dispersed across North America during most of the Pleistocene (Kurtén 1966, 1967).

After the Great American Biotic Interchange (GABI; Stehli \& Webb 1985), the subfamily Tremarctinae underwent a strong cladogenetic event in South America (Soibelzon et al. 2005), radiating five species
(Fig. 1A) attributable to Arctotherium (Soibelzon 2002, 2004). In the late Pleistocene, the Arctotherium lineage dispersed across South America (Fig. 1B) (Soibelzon 2002; Soibelzon et al. 2005), which probably foraged as omnivores and filled the guild of the earlier large Chapadmalania procyonids (Kragievlich \& Olazabal 1959). Finally, although the extinction of the short-faced bears in both North and South America was mostly synchronous, it was not the case with the spectacled bears (Soibelzon et al. 2005). In fact, tremarctines are still represented today in South America by the Andean bear, Tremarctos ornatus. The absence of earlier remains of this taxa in South America most probably indicates a second dispersal event during late Pleistocene or Holocene times (Trajano \& Ferrarezzi 1994; Soibelzon et al. 2005).

Therefore, the subfamily Tremarctinae is a monophyletic group of living and extinct bears (Fig. 1C) distributed from Alaska to Southern Patagonia (Soibelzon et al. 2005). Despite there being only a species, the subfamily was fairly diverse during the Pleistocene, and probably played a key role in the New World ecosystems. For this reason, the palaeobiology of tremarctines is crucial to provide a better understanding of the Ursidae evolutionary patterns under exceptional ecological conditions like the global climate change or rapid dispersal events. 


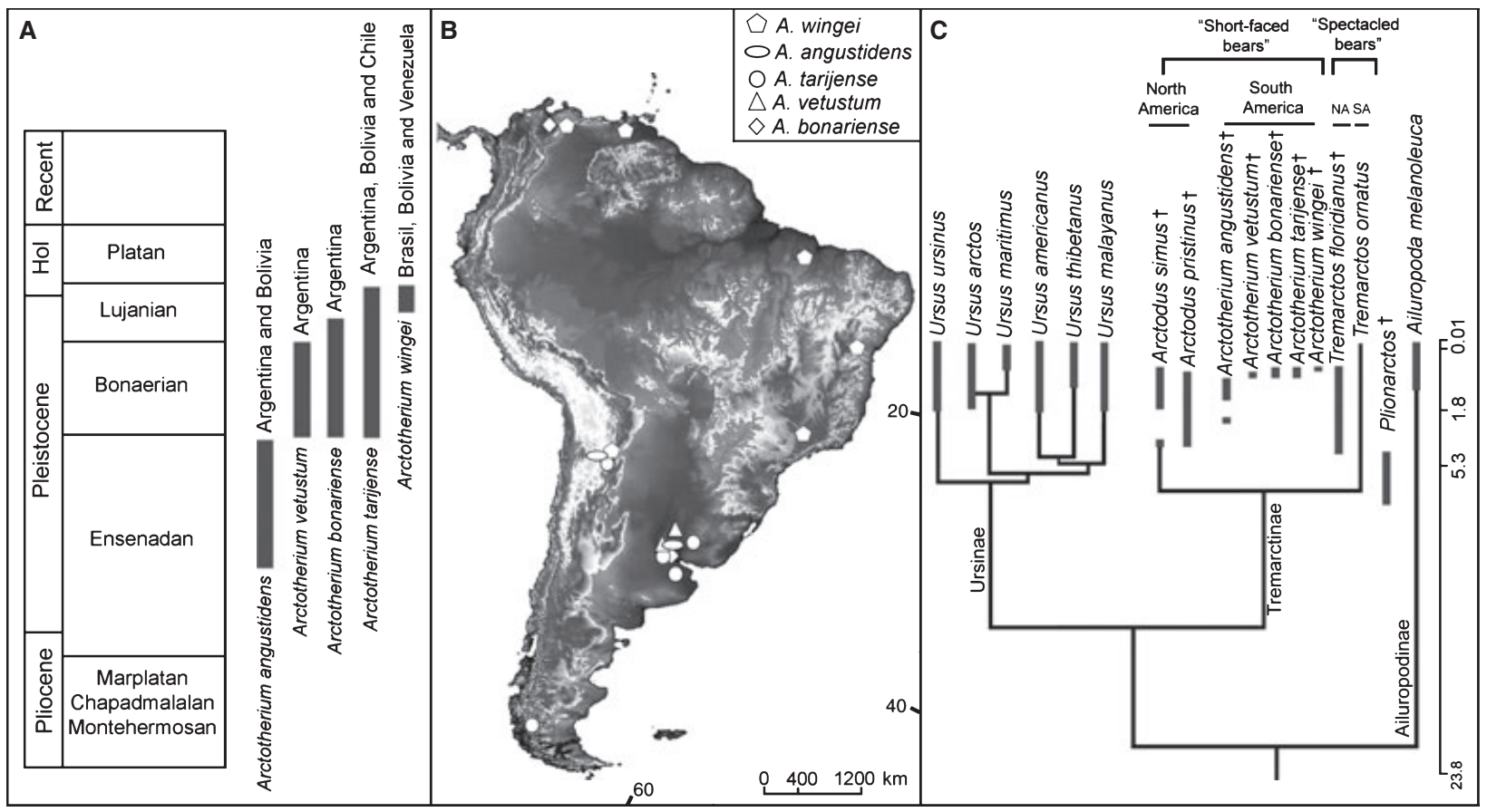

Fig. 1. Spatial and temporal distribution of the subfamily Tremarctinae. A, stratigraphic distribution of extinct South American tremarctines (modified from Soibelzon et al. 2005). B, geographic distribution of extinct South American short-faced bears during the Pleistocene (modified from Soibelzon et al. 2005). C, phylogenetic tree topology for all living bears and some extinct tremarctines, based on complete mitogenomic data from Krause et al. (2008). Vertical grey bars indicate temporal ranges based on fossil evidence.

Previous studies have reported a strong correlation among some autoecological factors (i.e. feeding preferences) and the craniodental anatomy of bears (Mattson 1998; Sacco \& Van Valkenburgh 2004; Christiansen 2007, 2008; Figueirido et al. 2009). However, few attempts have been made to understand the patterns of morphological evolution and palaeoautoecology in extinct tremarctines. In general, palaeobiological studies of large extinct South American carnivores are much scarcer compared with the studies on the North American taxa (Prevosti \& Vizcaíno 2006). For example, several papers have dealt with the palaeoautoecology of A. simus (e.g. Kurtén 1967; Emslie \& Czaplewski 1985; Matheus 1995; Sorkin 2006; Figueirido et al. 2009), but little is known about their South American vicars of the genus Arctotherium under a palaeobiological standpoint.

In this article, we explore the morphological evolution of the craniomandibular skeleton in tremarctine bears using a geometric morphometrics-based approach. This could contribute crucial information about the evolution and palaeobiology of bears under exceptional ecological conditions like global climate changes or rapid dispersal events. Therefore, the main goals of this paper are to: (1) explore the range of skull morphological variation among living and extinct tremarctine bears; (2) conduct ecomorphological inferences in extinct taxa, contributing to the scarce palaeoecological knowledge of the large carnivore guild in South America during the Plio-Pleistocene; (3) debate on those factors that could have played a major role in driving the skull shape evolution in tremarctines.

\section{The database}

The coordinates of a series of 10 relocatable landmarks (LMs) in the mandible, and 15 in the skull (Fig. 2; Table 1) were digitized from high-resolution digital images (2-D analysis) of living and extinct bears.

The digital images of living bears were collected by B.F. in the American Museum of Natural History (AMNH; New York, USA), the Natural History Museum (NHM; London, UK) and the Museum für Naturkunde (MFN; Berlin, Germany). The skull data set comprises 143 crania and 145 mandibles belonging to different individuals of all living ursid species.

The database of extinct species was collected by L.H.S. at several institutions in Argentina and the USA: Museo Argentino de Ciencias Naturales 'Bernardino Rivadavia' (MACN; Argentina), Museo Municipal de Mar del Plata 'Lorenzo Scaglia' (MMMP; Argentina), Museo Municipal 'Punta Hermengo' (MMPH; Argentina), Museo y Archivo Regional 


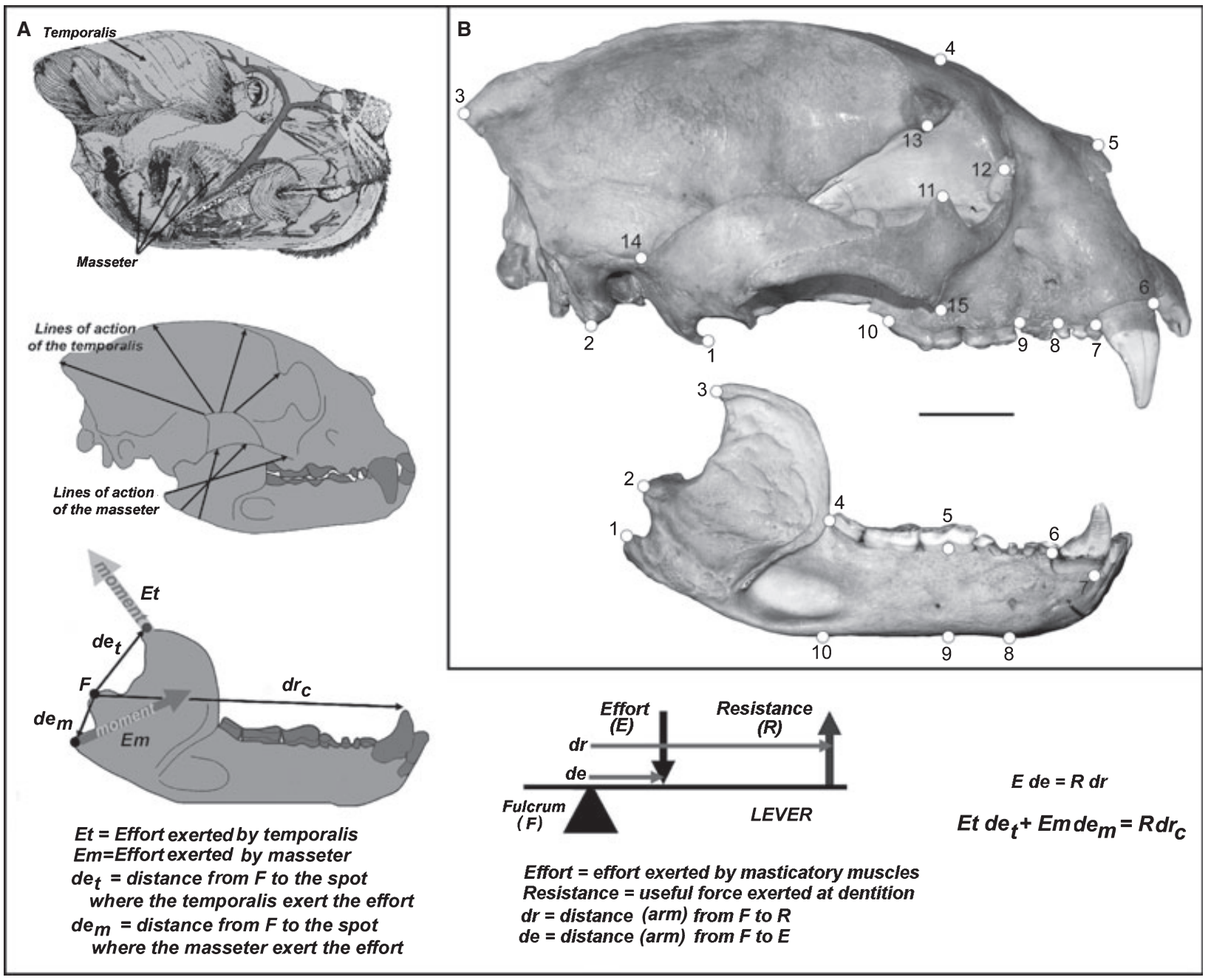

Fig. 2. Functional explanation (A) for the landmarks used in the relative warp analyses for describing skull shape (B). Scale bar equals $10 \mathrm{~cm}$. Left upper drawing, modified from Davis (1955).

Castelli (MARC; Argentina), Instituto de Geociencias, Universidade de Sao Paulo (GP; Brazil) and the University of Florida (UF; USA).

The fossil specimens included in the analyses comprise the complete crania and mandibles of all the extinct species of tremarctine bears described from the Americas, with the only exception of those species belonging to Plionarctos (see Fig. 3). As regards the South American taxa, we have included one complete cranium (MMMP-1233M) and one complete mandible (MACN-1201) of Arctotherium vetustum, one complete skull of Arctotherium bonariense (MARC 10232a2/242), one complete cranium (MACN 971) of Arctotherium tarijense, two complete skulls of Arctotherium angustidens (MMMPH 018 and MACN-43) and one complete cranium of Arctotherium wingei (GP/2T-4). All the specimens come from Argentina with the only exception of $A$. wingei, which was collected from Brazil. The North American tremarctines analysed were two complete skulls of A. simus, one from Indiana (PM-24880) and the other from Nebraska (F:AM-25535), one complete skull (UF 154288) of A. pristinus, one complete cranium (UF 7454) and two complete mandibles (UF-7454 and UF-8526) of $T$. floridanus from Florida.

\section{Morphometric analysis}

The landmark coordinates were digitized in all the specimens, both living and extinct, using the tpsDigv2.05 software (Stony Brook State University, New York, NY, USA; available at <http://life.bio.sunysb.edu/morph/>) (Rohlf 2006a). All the LMs were selected to capture the functional key points that accurately describe mandible and cranial shapes in bears. Special attention was paid to the shape of the forehead, the proportions between the neurocranium and 
Table 1. Landmark definitions (see also Fig. 3).

\begin{tabular}{cl}
\hline Landmarks & \\
\hline Mandible & Tip of angular process \\
1 & Most posterior edge of the articular surface condyle \\
2 & Most posterior edge of the coronoid process \\
3 & Posterior edge of the lower tooth row \\
4 & Intersection between the trigonid/talonid notch of \\
5 & the lower carnassial \\
6 & Postero-dorsal border of the canine alveolus \\
7 & Antero-dorsal border of the canine alveolus \\
8 & Most ventral point of the symphyseal region \\
9 & Ventral outline below the trigonid/talonid notch of \\
& the lower carnassial \\
10 & Ventral outline below the posterior end of the tooth \\
Crania & row \\
1 & Ventral tip of postglenoid process \\
2 & Ventral tip of the mastoid process \\
3 & Most postero-ventral point of the occipital crest \\
4 & Dorsal outline directly superior to postorbital process \\
5 & Most anterior edge of the nasals \\
6 & Most antero-dorsal border of the canine alveolus \\
7 & Most postero-dorsal border of the canine alveolus \\
8 & Most antero-dorsal border of the upper carnassial \\
9 & Point between the upper carnassial and the first upper \\
10 & molar \\
11 & Posterior edge of the upper tooth row \\
12 & Dorsal tip of the frontal process of the zygomatic arch \\
13 & Orbit midheight \\
14 & Ventral tip of the postorbital process \\
15 & Most postero-dorsal border of the zygomatic arch \\
& the maxilla \\
&
\end{tabular}

the splanchocranium, the position of the orbits, the relative size of the upper post-canine dentition and the development of canines. In the mandible, we captured the moment arms of masseter and temporalis muscles, the position of the jaw condyle in relation to the tooth row, the outlever moment arms at the carnassials and canine teeth, the bending strength of the horizontal ramus at different interdental gaps, and the lengths of the grinding and slicing dentitions. For the anatomical definition of these LMs, see Table 1.

The moment arms of the masseter and temporalis muscles, estimated here by the distances between LMs 1 and 2 and between LMs 2 and 3, respectively (Fig. 2B, mandible), depend on the shape of the areas of origin and insertion of these muscles in the cranium and mandible (Fig. 2A). The geometry of the masticatory muscles in carnivores was reported by Turnbull (1970) and specifically for bears by Davis $(1955,1964)$. The action lines of the temporalis and masseter (Fig. 2A) were generalized for all carnivores by Ewer (1973). Given that the action lines of these adductor muscles have been reported in bears by Davis (1955), we assume that the distance between the tip of the coronoid process (i.e. the point where the temporalis exerts its main input force) and the articular condyle (i.e. the fulcrum of the lever) measures the moment arm for the temporalis muscle (Fig. 2A). Similarly, the distance between the tip of the angular process (i.e. the point where the masseter exerts its main input force) and the articular condyle may be considered as a good estimator of the moment arm for the masseter muscle (Fig. 2A). In fact, these distances have been used as estimates of the moment arms of the masticatory muscles by several researchers (e.g. Van Valkenburgh \& Ruff 1987; Biknevicius \& Van Valkenburgh 1996; Christiansen 2005; Palmqvist et al. 2007).

A major limitation of using landmark-based methods with fossils is that only well-preserved, undeformed and complete specimens can be used (Slater \& Van Valkenburgh 2008). This fact prevents us from covering the shape of the upper incisive portion, or the overall shape of the hind head, because some fossil taxa do not preserve these anatomical regions. Besides, the information about the degree of the development of the premasseteric fossa among tremarctines was uncovered in our analysis given the absence of the biological homology among the specimens of the sample (the premasseteric fossa does not develop in living ursine bears).

The sample was split into two subsamples (mandibles and crania), and a separate morphometric analysis was computed for each one to include those fossil specimens preserved as isolated crania or jaws. Both subsamples were aligned using the generalized Procrustes Superimposition Procedure (GPA; Bookstein 1991; Adams et al. 2004; Marugán-Lobón \& Buscalioni 2006), and the consensus configuration (mean shape) was derived. Partial warps (PWs), which account for the differences in shape between a given shape (target) and the consensus configuration (mean), were calculated by giving an equal weight to the small and large spatial scales of the final form $(\alpha=0)$ (Rohlf 1993). All the uniform (i.e. affine) and non-uniform (i.e. non-affine) components of shape change were computed together. PW scores may be considered shape variables and are, thus, suitable for use in multivariate ordination techniques. Basically, the relative warp (RW) analysis is a principal components analysis (PCA) of the PW scores, performed using the covariance matrix (Rohlf 1993). Like the PCA of the linear measurements, the new orthogonal variables, now called RWs, summarize the original variance of the total sample. The significance of RWs was evaluated representing graphically the eigenvalues from the RW analyses against their ranks. In this kind of graphs, we can detect differences between the main factors attending to morphological variation within the data by means of substantial breaks in the slope of the decay of the eigenvalues. The RW analysis was computed using the tpsRelw.v1.44 software (Stony 

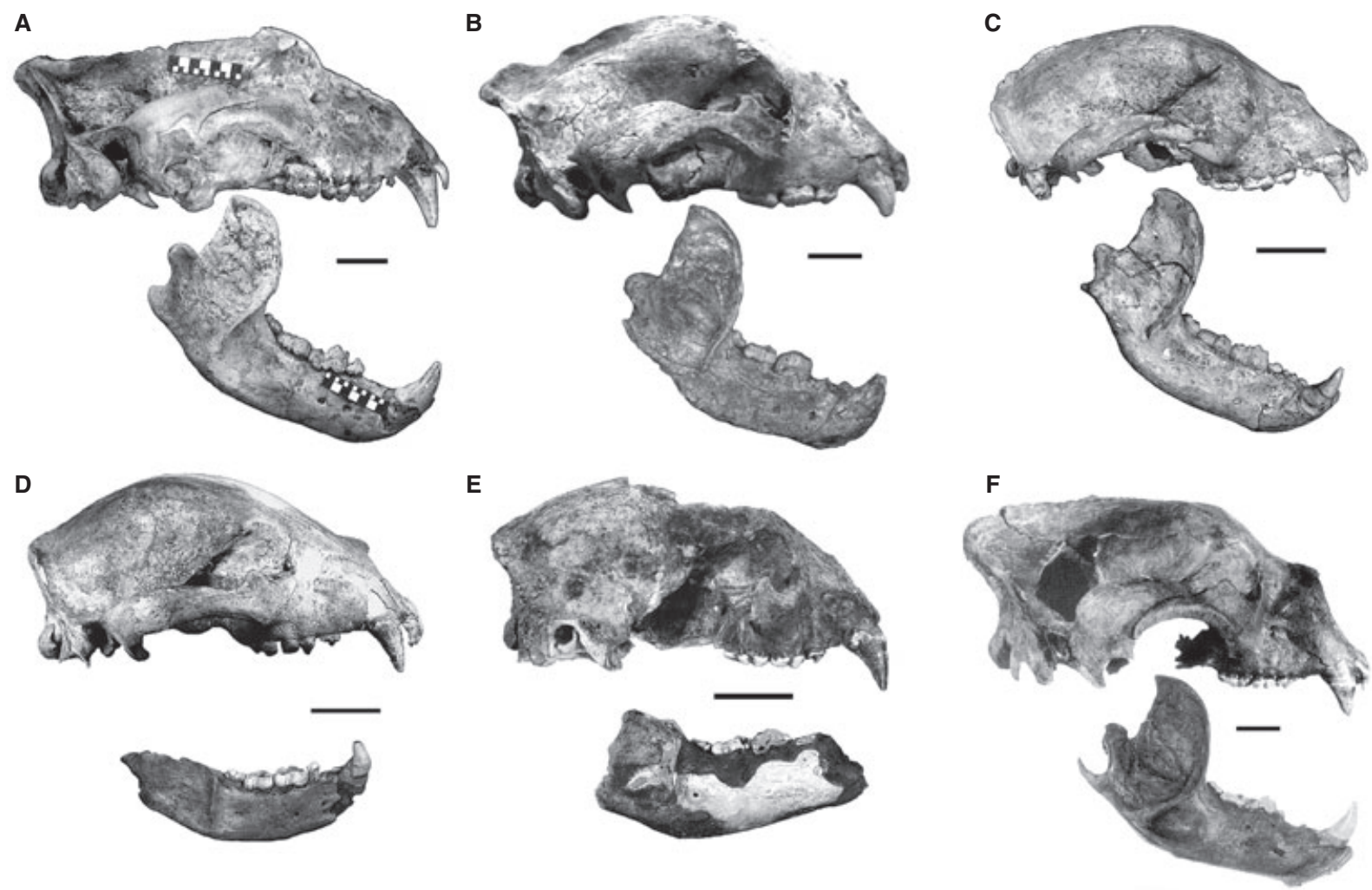

G

H
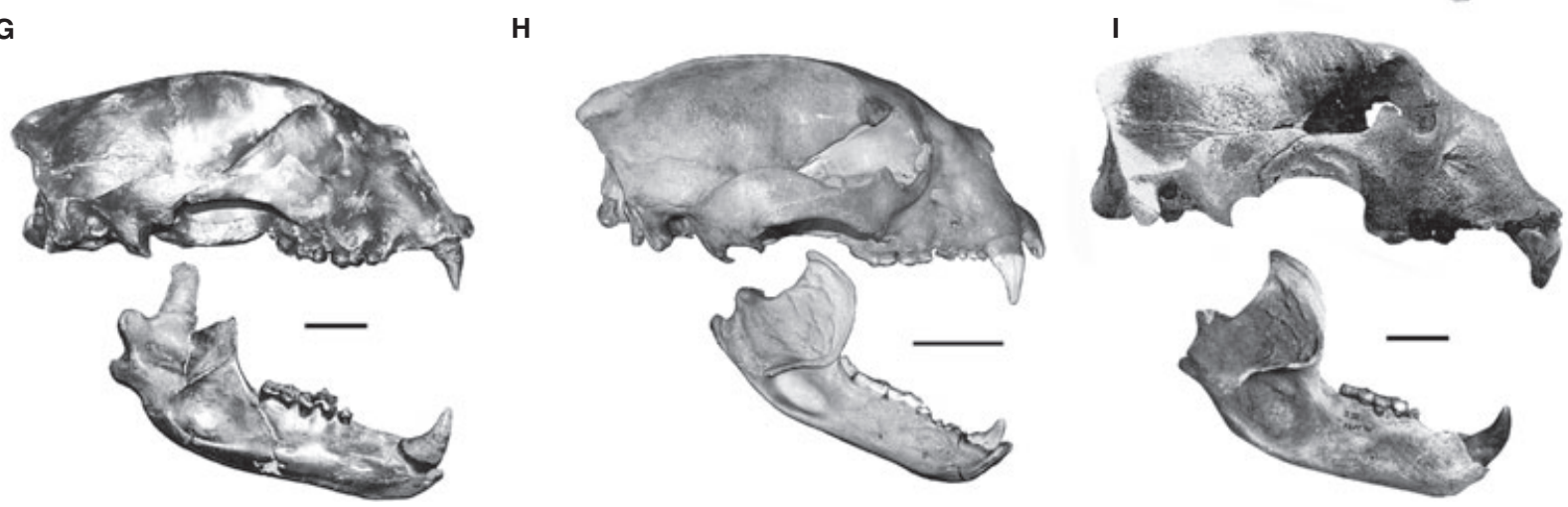

Fig. 3. Living and extinct $(\dagger)$ tremarctine bears included in this paper. A, Arctotherium angustidens $\dagger$ (MMMPH018); B, Arctotherium bonariense $\dagger$ (MARC 10232a2/242); C, Arctotherium vetustum † (MMMP-1233M; MACN-1201); D, Arctotherium tarijense $\dagger$ (MACN-971); E, Arctotherium wingei $(\mathrm{GP} / 2 \mathrm{~T}-4) ; \mathrm{F}$, Arctodus simus $\dagger(\mathrm{PM}-24880) ; \mathrm{G}$, Arctodus pristinus $\dagger$ (UF-154288); H, Tremarctos ornatus; I, Tremarctos floridanus $\dagger$ (UF-7454). Scale bar equals $5 \mathrm{~cm}$. The specimen PM-24880 was taken from Richards \& Turnbull (1995).

Brook State University, New York, NY, USA; available at $<$ http://life.bio.sunysb.edu/morph/>) (Rohlf 2006b).

In order to explore the presence of allometric effects in the morphological variation explained by the significant warps, we computed bivariate graphs among the scores of these warps and the logarithm of centroid size (Cs) (Bookstein 1991). It is worth noting that a multivariate regression analysis among the shape of the skull and the logarithm of Cs could reveal allometric relationships within the sample. However, we only want to explore the allometric effects present in the significant warps rather than in all the warps derived from the multivariate analyses of landmark data.

For the purpose of interpreting the ecomorphological comparisons among the living bears included in the sample and inferring feeding behaviour in fossil taxa, the eight living ursid species were distributed among three broad dietary categories following Figueirido et al. (2009): (1) vegetal matter feeders, including the strict herbivore giant panda Ailuropoda melanoleuca (Schaller et al. 1989) and the mostly herbivore spectacled bear T. ornatus (Peyton 1980); (2) omnivores, with a diet that includes 
variable proportions of animal and plant resources, depending on their availability. This feeding category includes the American black bear, Ursus americanus (Pelton 1993), the brown bear, Ursus arctos (Pasitschniak-Arts 1993), the sun bear, Ursus malayanus (Fitzgerald \& Krausman 2002) and the Asiatic black bear, Ursus thibetanus (Reid 1993); and (3) animal matter feeders, feeding predominantly on animal resources, including the polar bear, Ursus maritimus (DeMaster \& Stirling 1981) and the sloth bear, Ursus ursinus (Joshi et al. 1997). However, although these feeding groups are not homogeneous, the low taxonomic diversity of the living ursids precludes the use of more specific ecological categories. In addition, pooling these two species in one category helps to avoid the possibility for interpreting only interspecific differences of these two bears (i.e. autoapomorphic characters) instead of focusing on those morphological traits indicative of differences in feeding behaviour.

\section{Skull morphology}

Figure 4 shows the scores of the overall sample (living and extinct) on the morphospace depicted by the first two RWs from the mandible shape analysis. Although the first four RWs' axes were significant, we only present the results of the first two RWs ( $>70 \%$ of the original variance explained), mainly because the rest highlighted very few taxa. It is worth noting that the bivariate plots among the log of Cs (Bookstein 1991) and the scores of the first two RWs indicate that the shape change explained by these warps does not result from allometric effects.

The first two RWs primarily distribute the living species according to feeding preferences, and only secondarily with their phylogenetic affinities. In fact, the first RW partially correlated with a feeding gradient (Fig. $4, x$-axis). For example, the highly herbivorous giant panda (A. melanoleuca) and the almost

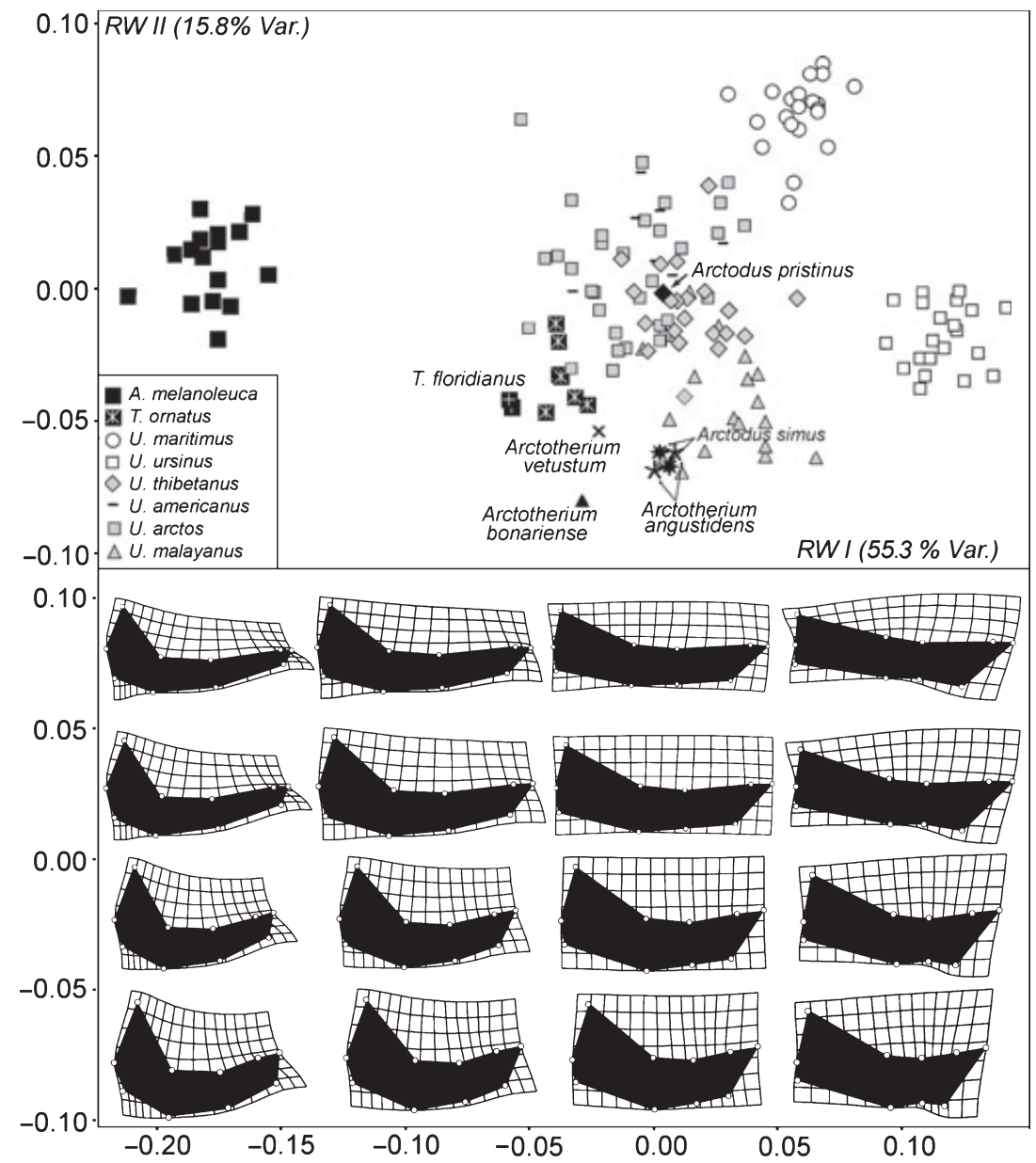

Fig. 4. Morphospace depicted by the first two relative warps from mandible morphology and thin-plate spline diagrams showing the morphological variability in bear mandibles along these warps. Black symbols: vegetal matter feeders; grey symbols: omnivores; white symbols: animal matter feeders. 
entirely herbivorous spectacled bear ( $T$. ornatus) present scores with extreme negative values on this axis (Fig. 4, $x$-axis), although there is a slight overlap among the spectacled bear and the brown bear. This is also the case of the extinct North American spectacled bear ( $T$. floridanus). According to the TPS diagrams, the mandibles of extant herbivorous bears and extinct $T$. floridanus are concave and short, have large moment arms for the temporalis and masseter muscles with a condyle placed well above the level of the tooth row, and present the horizontal ramus shallow at the level of the canine and very deep below the third molar. Finally, herbivorous bears also show well-developed cheek teeth (Fig. 4, $x$-axis).

Unlike herbivorous bears, with scores showing the highest positive values on this axis (Fig. $4, x$-axis), we find those bears that feed predominantly on animal matter (i.e. the highly carnivorous polar bear, U. maritimus, and the highly insectivore sloth bear, U. ursinus). However, as in the case of the spectacled bear, the polar bear shows a slight overlap with some omnivorous bears in this axis (Fig. 4, x-axis). According to the TPS diagrams, the mandible of bears that feed primarily on animal matter is characterized by a distinct jaw anatomy relative to herbivores because their mandibles are larger and more convex, have smaller moment arms for the temporalis and masseter muscles, have a condyle at the same level of the tooth row and have a deeper mandibular symphysis and reduced cheek teeth (Fig. $4, x$-axis). In an intermediate position to those bears that feed predominantly on plant or animal matter we find those bears that feed on a broad array of items, like fruits, insects, vertebrate flesh or carrion, depending on resource availability (i.e. omnivores).

In addition, both North (A. simus and A. pristinus) and South American (Arctotherium angustidens) short-faced bears are plotted within the living omnivorous bears in the morphospace depicted by the first two RWs derived from the mandible analysis. It is worth noting that Arctotherium angustidens are separated from the rest of the South American short-faced bears on this axis, which were their closest relatives. As expected, the mandible morphology of the omnivorous bears and of these three extinct species is intermediate between the mandible of those bears that habitually consume animal and plant resources (Fig. 4, $x$-axis).

The South American short-faced bears, Arctotherium vetustum and Arctotherium bonariense, are plotted in an intermediate position between the spectacled bears ( $T$. ornatus and T. floridanus) on the one hand and the living omnivores plus Arctodus and Arctotherium angustidens on the other (Fig. $4, x$-axis).
Within the animal consumption category, the second RW mainly separates the polar bear, which feeds predominantly on vertebrate flesh (DeMaster \& Stirling 1981), from the highly insectivore sloth bear (Joshi et al. 1997). However, the specimens with the lowest negative values on this axis are the living sun bear (U. malayanus), plus the extinct A. simus, Arctotherium angustidens and, especially, Arctotherium bonariense. Thin plate spline diagrams show that these species have a comparatively short and deep horizontal ramus, a large moment arm for the temporalis muscle, and that they also display large canines. All these characteristics give them a stoutly built appearance. By contrast, the jaw of the polar bear (with the highest positive scores on this warp) is longer and shallower than that of other bears and has a smaller moment arm for the temporalis muscle (Fig. 4, $y$-axis). It is worth noting that this axis also separates the two North American short-faced bears species, $A$. simus and $A$. pristinus (Fig. 4, $y$-axis). Indeed, the $A$. simus specimens have a concave jaw, large masseter and temporalis muscles, deeper horizontal ramus and a reduced slicing dentition length, which relate to $A$. pristinus. This axis also separates the Arctotherium vetustum specimens from those of Arctotherium bonariense (Fig. 4, $y$-axis).

Figure 5 illustrates the scores of the overall sample on the morphospace depicted by the first two RWs derived from the cranial analysis. We show only the results obtained with the first two RWs, which jointly account for more than $60 \%$ of the explained variance because the other five significant warps mainly highlighted very few taxa (except the third RW). Within the animal consumption category, the third RW (8.5\% of the original variance explained) mainly separates insectivores from carnivores, which are omitted here because all the tremarctines included in the analysis are plotted within the omnivorous or herbivorous bears. As with the mandible analysis, the bivariate plots between the Cs and the scores of these warps allowed us to reject any allometric effects.

As expected, the results obtained with the cranial analyses are similar to those obtained with the mandible analyses (at least for the extant species). The first RW mainly explains the morphological changes that correlate with feeding behaviour. Herbivorous bears score negatively ( $T$. ornatus and A. melanoleuca), which may also be said of the extinct species Arctotherium vetustum, and especially Arctotherium wingei. It is worth noting that the spectacled bear is slightly overlapped with other omnivorous bears (Fig. 4, $x$ axis) which could reflect their lesser specialized diet to feed on vegetal resources relative to giant panda or its shorter divergence times (Fig. 1). Therefore, according to the morphological changes explained by the first 


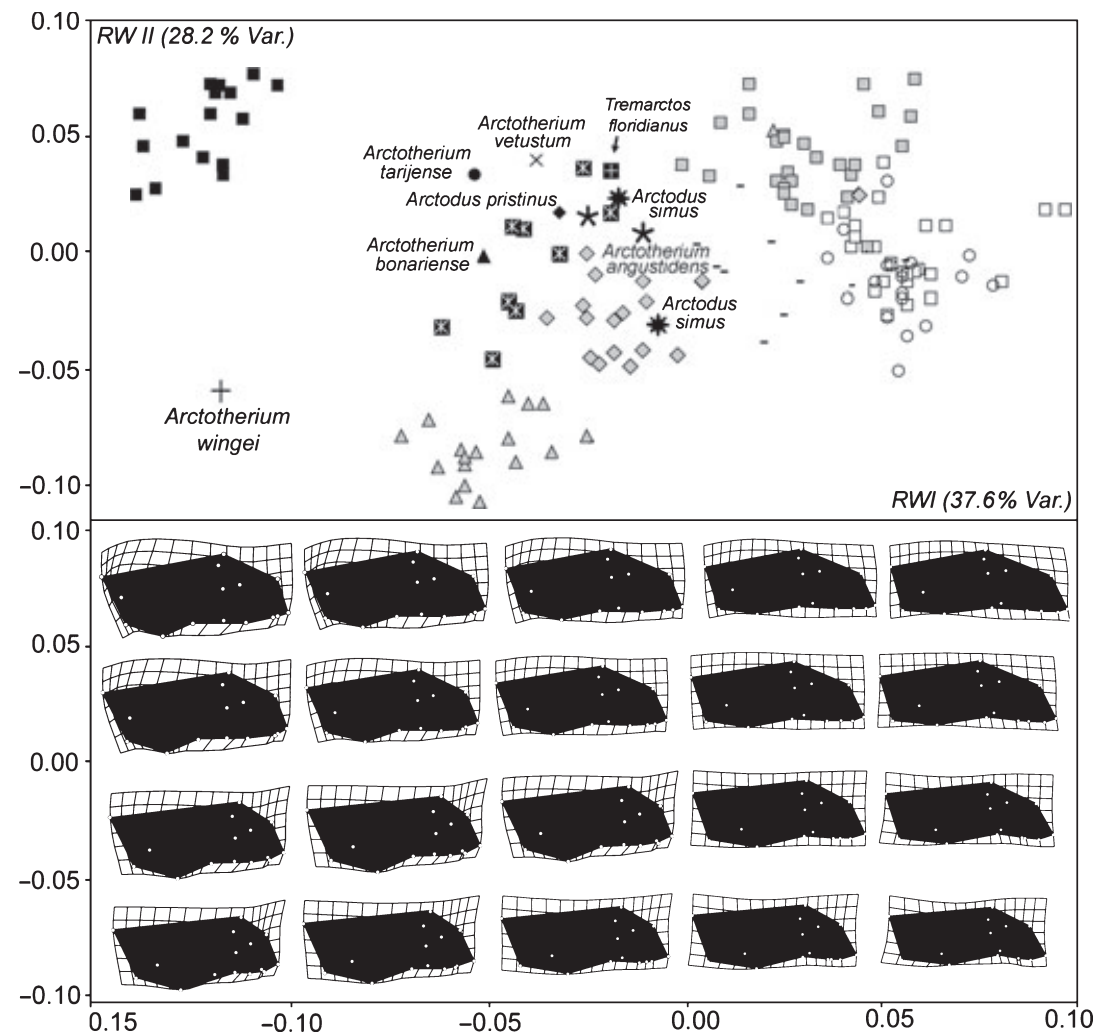

Fig. 5. Morphospace depicted by the first two relative warps derived from cranial morphology and thin-plate spline diagrams showing the morphological variability in the bear crania along these warps. Symbols as in Figure 4.

RW (Fig. 5, $x$-axis), the crania of those bears that feed on plant matter are short and deep, have straight and well-developed zygomatic arches, stoutly post-glenoid processes, and show low, big and lateralized orbits. They also present small canines and well-developed tooth rows (Fig. 5, $x$-axis). By contrast, those bears that feed on animal resources ( $U$. maritimus and $U$. ursinus) score positively on this axis (Fig. 5, $x$-axis). However, there is a high overlap among these bears and some specimens of $U$. arctos and $U$. americanus in this axis. All of them have larger and shallower crania, medially vaulted calvaria, display smaller zygomatic arches that are posteriorly oriented downward, and have small, elevated and frontalized orbits. They also display well-developed canines and a reduced postcanine dentition (Fig. 4, x-axis). The omnivorous bears together with one specimen of Arctotherium angustidens and one specimen of $A$. simus take intermediate scores between those species that specialize in feed animal and plant matter. The cranial morphology of omnivores is intermediate between the crania of those species that mainly consume animal or plant resources.

The second RW (Fig. 5, $y$-axis) separates the specimens of sun bears ( $U$. malayanus) from the specimens of brown bears ( $U$. arctos), which scored the most negative and positive values in this warp respectively. According to the TPS diagrams, the skull of the sun bears is characterized by it having a short rostrum, small zygomatic arches and low-positioned orbits. Furthermore, they present a reduced premolar tooth row and well-developed canines. All these morphological characteristics give them a stoutly built appearance (Christiansen 2007; Figueirido et al. 2009). By contrast, brown bears present larger crania with a more developed rostrum, and have broader zygomatic arches, more elevated and frontalized orbits and welldeveloped tooth rows (Fig. 4, $y$-axis).

\section{Feeding behaviour in extinct taxa}

The skull morphology of living bears correlates highly with their feeding behaviour and their trophic preferences (Sacco \& Van Valkenburgh 2004; Christiansen 2007; Figueirido et al. 2009). However, while the morphology of the mandible is only involving in terms of food acquisition and processing, the morphology of the crania is the result of a compromise among different functions (e.g. feeding, olfactory sense, vision and brain processing). Consequently, the mandible has a greater evolutionary plasticity than the crania that 
have a higher degree of morphological integration and evolutionary conservatism (Barone 1986; Figueirido et al. 2009). Therefore, as the morphology of the cranium reflects conflicting functional demands (Vizcaíno \& Bargo 1998), the mandible is better adapted towards feeding behaviour than the cranium. For this reason, the mandible morphology is an excellent choice to explore the different feeding strategies of the extinct tremarctine bears through evolution.

According to the mandible analysis, the two specimens of the North American spectacled bear (T. floridanus) are plotted with their closest living relative, $T$. ornatus (Fig. 4). It is worth noting that T. ornatus is almost entirely herbivorous, although it occasionally takes vertebrates as its prey (Peyton 1980). Although this morphological resemblance between the North and South American spectacled bears could reflect genealogy (Fig. 1A), the mandibular morphological traits recognized in $T$. floridanus have been previously reported as adaptations in bears to herbivory. These characteristics are, for example, the presence of a short and concave mandible, a deep horizontal ramus (mainly below the third molar), large masseter and temporalis muscle leverages and large lower post-carnassial molars (Davis 1955; Christiansen 2007; Figueirido et al. 2009). According to these morphological characteristics, T. floridanus could have adapted to feed almost entirely on plant resources, although, as mentioned above, we cannot rule out the possibility that this morphological resemblance between living and extinct spectacled bears reflects their phylogenetic affinities.

As evidenced by the first two RWs derived from the mandible analysis, the mandible shape of the giant South American short-faced bear, Arctotherium angustidens, is very similar to the mandible shape of the giant North American short-faced bear, A. simus. It is worth noting that the two Arctotherium angustidens specimens are plotted far from their South American relatives, Arctotherium vetustum and Arctotherium bonariense (Soibelzon 2002). In addition, the two A. simus specimens are plotted far from their closest North American relative (and most probably its ancestor; Kurtén 1967), A. pristinus (at least in the second RW). This morphological similarity in the mandible anatomy of these North and South American shortfaced bears probably reflects an evolutionary convergence to the same foraging strategy instead of a result of genealogy.

Several authors have suggested that the North American short-faced bear A. simus was largely carnivorous and their suggestions were based on morphological (e.g. Kurtén 1967; Kurtén \& Anderson 1980) and isotopic (e.g. Bocherens et al. 1995; Matheus 1995) evidence. However, on the basis of a broad morphological study of living and extinct bears, Figueirido et al. (2009) found evidence to support the statement that the short-faced bear was mainly omnivorous, although its diet would have included a variable proportion of meat depending on its availability. In this way, the Beringian populations of A. simus could have eaten a considerable amount of meat, following Matheus (1995), although in a similar way as the northern populations of the living brown bears do today.

Therefore, this resemblance in mandible morphology among the giant short-faced bears from both North (A. simus) and South America (Arctotherium angustidens) probably reflects that Arctotherium angustidens were mainly omnivorous. However, as with $A$. simus, the diet of the giant South American short-faced bear could have most probably included a considerable amount of animal matter. In fact, Arctotherium angustidens is the first bear to be registered in the South American fossil record after the GABI, when the Ensenadan ecosystems were characterized by a large number of herbivorous megamammals (e.g. Glyptodon munizi, Macraucheniopsis ensenadensis, Megatherium gallardoi and Panochthus intermedius), and only one carnivore rivalled this bear in terms of size, the sabre-toothed cat Smilodon populator (Prevosti \& Vizcaíno 2006; Soibelzon et al. 2009). It is worth noting that other members of the carnivore guild were present in the Ensenadan ecosystems (e.g. Theriodictis platensis, Canis gezi or Panthera onca), but none of them rivalling in size with the large Arctotherium angustidens. In addition, the Bonaerian-Lujanian ecosystems were more mature relative to the Ensenadan ones, mainly because the large carnivores that arrived in South America from the northern continents after the GABI experimented during the Ensenadan a strong adaptative radiation, and consequently the different niches were progressively invaded. Therefore, with the exception of bears, the large carnivore fauna of the Bonaerian-Lujanian were more specialized relative to the Ensenadan ones.

With this ecological scenario, in which potential preys were abundant and with only one possible competitor, it is feasible that the diet of Arctotherium angustidens included a considerable amount of meat (Soibelzon \& Prevosti 2007). In fact, a large proportion of Arctotherium angustidens specimens show broken teeth (Fig. 6A), most probably as a result of chewing on hard objects like bones (Soibelzon et al. 2009). Obviously, this evidences that carcass consumption could have been a potential source of feeding for this giant South American short-faced bear (Soibelzon \& Prevosti 2007). However, we do not state that Arctotherium angustidens was a specialized scavenger or a fast cursorial predator, rather we believe 


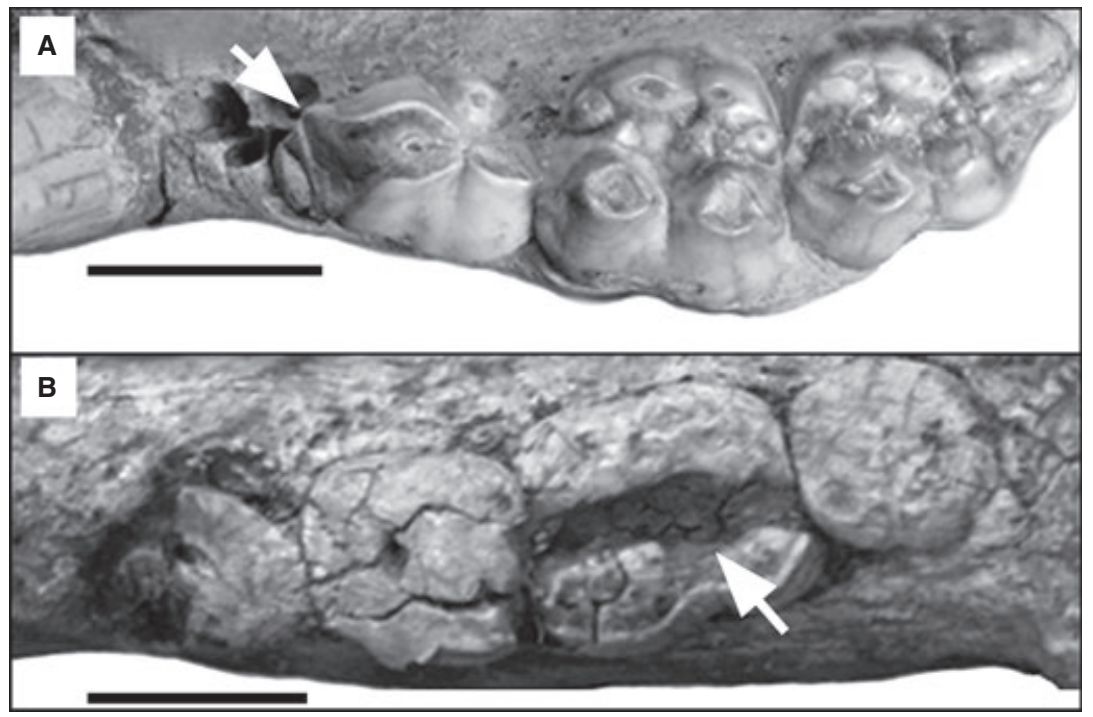

Fig. 6. Broken teeth in the short-faced bears. A, upper dentition of Arctotherium angustidens. Note the damaged upper carnassial (white arrow). B, lower dentition of Arctotherium bonariense. The second molar is broken along its antero-posterior axis (white arrow). Scale bars $3 \mathrm{~cm}$.

that the giant and South American short-faced bear was mainly omnivorous, and had ecological opportunities and morphological capabilities to feed on carcasses or meat whenever these resources became available. The fact also remains that Arctotherium angustidens have only been recovered from Argentina (in the province of Buenos Aires) and Bolivia (in the Tarija Valley), which could bias the ecomorphological inferences in this extinct species.

The Arctotherium vetustum and Arctotherium bonariense specimens are plotted in an intermediate position between the Arctotherium angustidens plus the A. simus on the one hand, and the T. ornatus plus the T. floridanus on the other (Fig. 4). This intermediate mandible morphology, between omnivore and highly herbivore bears (at least in the case of the living T. ornatus) suggests that their diet could have included a considerable amount of plant matter. It is worth noting that these two bears plus Arctotherium tarijense were dispersed in both the Bonaerian (Middle Plesitocene) and the early Lujanian (Late Pleistocene) across South America (Soibelzon et al. 2005) when a wide array of large carnivores composed the large carnivore guild (Prevosti \& Vizcaíno 2006). Among them, felids (Smilodon populator, Puma concolor and Panthera onca) and canids (Canis dirus, Protocyon sp., Canis nehringi and Spheotos sp.) were certainly hypercarnivorous and preyed on medium-sized and large mammals (Sillero-Zubiri et al. 2004; Prevosti \& Vizcaíno 2006). It is worth noting that the sabre-toothed cat could have also preyed on megamammals (Prevosti \& Vizcaíno 2006). Therefore, the Lujanian bears (Arctotherium bonariense, Arctotherium tarijense, and most probably Arctotherium vetustum) certainly had more possible competitors related to the Ensenedan Arctotherium angustidens.

However, in spite of the morphological resemblance in the RWI between Arctotherium vetustum and Arctotherium bonariense, they are seen to differ considerably in the RWII where the Arctotherium bonariense take scores with the lowest negative values on this axis (Fig. 4, $y$-axis). This fact indicates that the mandible of Arctotherium bonariense is very deep, with extremely large temporalis and masseter muscles leverages, and that it has a large canine and well-developed check teeth compared with the mandible of Arctotherium vetustum. All these characteristics are partly shared with the living omnivorous bears, although Arctotherium bonariense has an extremely heavily built mandible (see Fig. 3). Besides, Soibelzon et al. (2009) stated that a good number of Arctotherium bonariense specimens, for instance Arctotherium angustidens, show damaged teeth as a result of chewing on hard objects like bones (Fig. 6B). Therefore, we believe that although $A$. bonariense was mainly omnivorous, this bear could certainly have scavenged the mammal carcasses left over by the hypercarnivorous members of the large carnivore guild despite its diet including a high percentage of plant matter. However, bears feed a wide array of other hard foods apart from bones, for instance, bark, hard fruits or different kinds of roots that could have damaged the teeth of the extinct Arctotherium bonariense.

The absence of completely preserved Arctotherium wingei mandibles leads us to derive some ecomorphological inferences from its cranial morphology. 
However, and as we discussed in the first paragraph of this section, the mandible morphology correlates more with feeding behaviour than the crania. If we bear this in mind, the cranial morphology of Arctotherium wingei scores negatively on the first RW and occupies an intermediate position between all the tremarctine bears and the giant panda. Indeed, its skull is shorter and deeper, has straighter and more developed zygomatic arches, and displays lower, bigger and more lateralized orbits than that of other tremarctines. According to this morphology, Arctotherium wingei could have been the most herbivorous bear of the South American Pleistocene. However, this skull belongs to an immature individual with permanent, fully erupted dentition (L.H.S., personal observation). This fact prevents us from safely stating that Arctotherium wingei was strictly (or at least almost entirely) an herbivorous bear. Future findings in the fossil record could provide crucial insights into the palaeobiology of this tremarctine which became recently extinct.

All tremarctine bears present similar cranial morphospace scores (Fig. 5), which opens up the possibility of exploring the combination of the cranial characteristics shared by all the tremarctines in relation to ursine or ailuropodine bears. The cranial morphology of tremarctines vastly differs from that of ursines. For example, their skulls are deeper and more brachycephalic, their zygomatic arches and glenoid fossas are well developed and they have larger molars in comparison with ursines (Fig. 5). Their orbits are also bigger, more rounded and lateralized. All these characteristics are extreme in ailuropodine bears (Fig. 5). If compared with the crania of tremarctines, those of Ailuropoda are deeper, have extremely developed zygomatic arches, their tooth rows are very well developed and they have bigger and lateralized orbits.

Strikingly, spectacled bears and short-faced bears do not considerably differ in terms of their snout length. This is also evident in the second RW derived from the cranial morphology (Fig.5, $y$-axis). Indeed, the snout of the living T. ornatus and that of some extinct tremarctines (i.e. Arctotherium wingei, Arctotherium bonariense, Arctotherium vetustum and A. pristinus) is slightly shortened when we compare it with that of other ursine or ailuropodine bears, except for U. malayanus (Fig. 7A). Other tremarctines (i.e. Arctotherium angustidens, Arctotherium tarijense, T. floridanus and $A$. simus) have never presented the shortened degree of the snout as that observed in $U$. malayanus. This is also evidenced by U. malayanus, T. ornatus, and by a large proportion of tremarctines (although to a lesser extent), which present shorter distances between the upper fourth premolar and the canine, unlike other ursine bears such as the polar bear or the giant panda (Fig. 7B). In fact, both giant panda and polar bears have backwardly positioned carnassials and, therefore, large distances between the
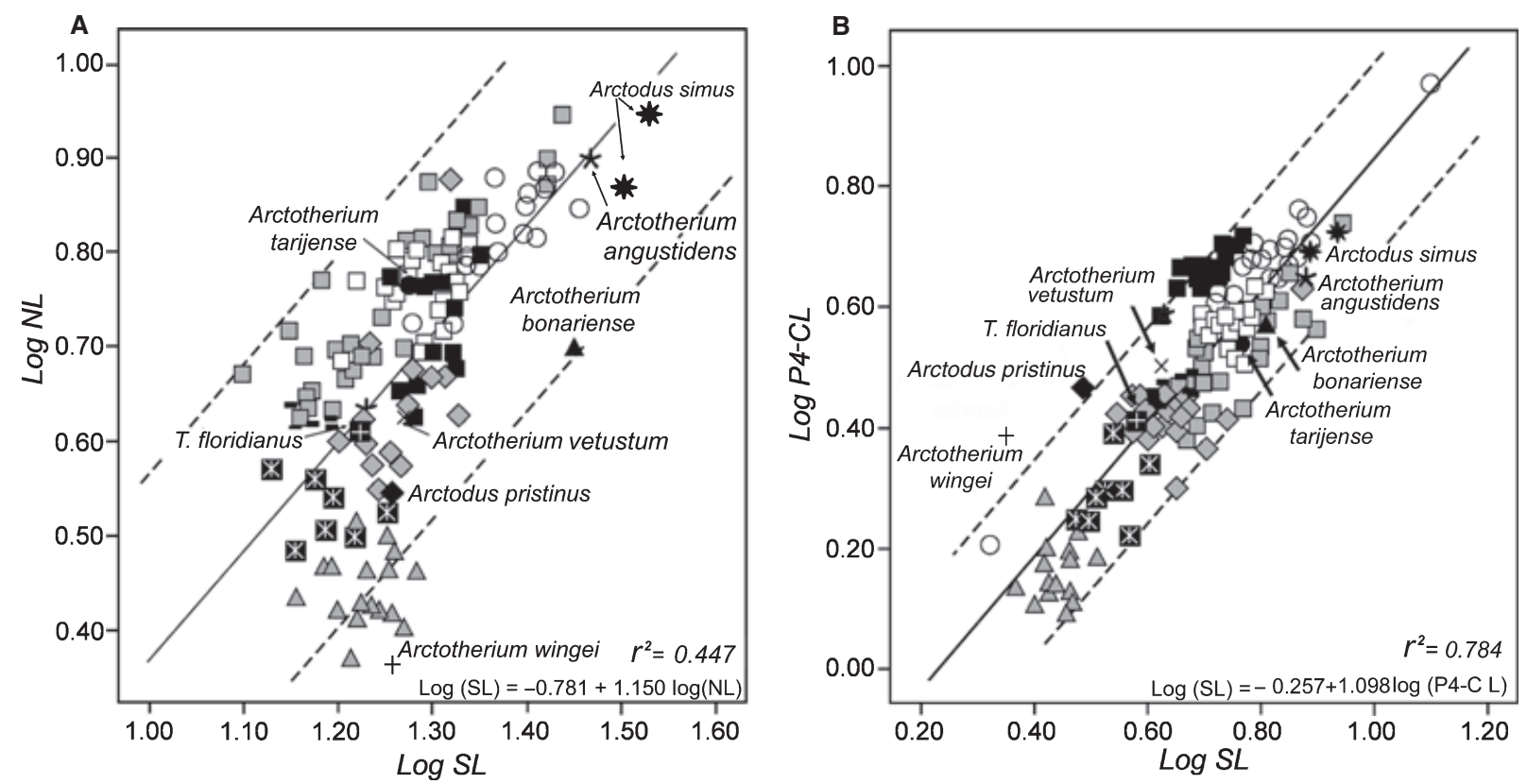

Fig. 7. Bivariate plots for cranial dimensions in bears (data log transformed). A, snout length (SL) on neurocranial length (NL); B, snout length (SL) on the length from the upper fourth premolar to canine (P4-C L). Interlandmark measurements were performed using the internet accessible landmark measurement Morpho-tools (Krieguer 2006). The SL is computed as the distance between the LM5 and LM12; NL as the distance between the LM3 and LM12; and the P4-C L was computed as the distance between LM7 and LM8. Symbols for the living specimens as in Figure 4. 
fourth upper premolar and the canine (Fig. 7B). However, this same solution may tackle different problems; the giant panda has extremely developed anterior premolars and its skull needs space to accommodate such teeth, while the polar could exert large bite forces with the carnassials by reducing the outlever moment arm to this tooth, and presents a long diastema between the upper fourth premolar and the canine. It is worth noting that the reduction in the outlever arm to this tooth in the polar bear could be counterbalancing the reduced moment arms for the temporalis and masseter muscles.

\section{Morphological patterns in South American Tremarctines}

Bears are one of the most ecologically and morphologically adaptable groups among the large carnivore guild. Omnivorous bears retain the ability to behave as carnivores or herbivores according to resource availability. Moreover, their skull morphology could reflect ecological adaptations under different selection pressures with the required evolutionary time (Sacco \& Van Valkenburgh 2004; Christiansen 2007; Figueirido et al. 2009). The adaptive radiation experienced by tremarctines in South America provides strong evidence of the remarkable evolutionary plasticity shown by the bears under different ecological conditions.

Before the GABI, the only large carnivores present in South America were medium-sized marsupial sabre-toothed cats (Thylacosmilus), omnivorous procyonids (Cyonasua and Chapadmalania) and phororhacoids birds (Stehli \& Webb 1985; Webb 1991; Soibelzon et al. 2009). However, the ecological scenario drastically changed after the Plio-Pleistocene boundary when the GABI took place (Stehli \& Webb 1985). This biotic interchange between North and South America through the Panamanian Isthmus was the cause of the arrival of short-faced bears to South America, along with other members of the mammalian order Carnivora (Soibelzon \& Prevosti 2007). In fact, Arctotherium angustidens was the largest and most powerful mammalian carnivore in the Ensenadan ecosystems of South America, rivalled only in size with the sabre-toothed cat, Smilodon populator. It is worth noting that among ursids, only some individuals of the northern A. simus (Cope 1879) attained the size of Arctotherium angustidens (Gobetz \& Martin 2001; Soibelzon 2002). There were also a large number of endemic herbivorous megamammals in the Ensenadan ecosystems (Soibelzon et al. 2009). For this reason, it seems probable that Arctotherium angustidens was an omnivore species whose diet included a considerable amount of meat in a similar way as some northern populations of living brown bears do today. In fact, some individuals of Arctotherium angustidens show damaged teeth as a result of chewing on hard objects like bones (Soibelzon et al. 2009). However, as their mandible anatomy demonstrates, Arctotherium angustidens was neither a hypercarnivore nor a specialized scavenger but, given the exceptional ecological conditions in which the potential prey items were abundant, and only one possible competitor, it is reasonable to propose that this short-faced bear was capable of preying on megamammals and of scavenging carcasses whenever the opportunity arose.

The mandible anatomy of the Bonaerian bears (Arcotherium vetustum and Arctotherium bonariense, and possibly Arctotherium tarijense) clearly suggests that their diets changed including a high percentage of plant matter. During the Bonaerian and Lujanian, medium-sized carnivores were highly diverse, and rivalled in size with the short-faced bears of that time (Soibelzon 2002). It is worth noting that Arctotherium vetustum and Arctotherium bonariense were relatively smaller compared with Arctotherium angustidens (Soibelzon 2002). However, Fariña (1996) estimated the biomass and energetic requirements of herbivores relative to carnivores based on species diversity and their estimated body mass. Fariña (1996) concluded that the community in South America during the Lujanian was unbalanced because the biomass of large herbivores greatly exceeded the energetic requirements of the large carnivores. Therefore, if we consider the 'imbalance hypothesys' of Fariña (1996), short-faced bears had enough prey available because the community of the Pampean region during the Lujanian enjoyed a remarkable diversity of megaherbivores in relation to the low richness and abundance of carnivores. Recently, however, Prevosti \& Vizcaíno (2006) updated the large carnivore guild in the Pampean region at that time. They concluded that there was no evidence to support that the densities of Lujanian carnivores were imbalanced in relation to the abundance of herbivores.

Finally, the small Arctotheirum wingei appeared in the fossil record during the early Holocene (at least in Venezuela), which became extinct at the end of the Lujanian (Fig. 1B). However, A. tarijense also has records in levels and localities dated for the latest Pleistocene (Soibelzon et al. 2005), but these two species shows different distributions, while A. wingei is distributed in northern latitudes (Bolivia, Brazil and Venezuela), A. tarijense is distributed in the southern ones (Bolivia, Uruguay, Pampean region and austral Patagonia). 
On the basis of cranial morphology of Arctotheirum wingei, we tentatively believe that this short-faced bear was almost entirely herbivore. However, as we have included only one specimen recovered from Brazil, it is worth noting that this bear could have specialized to its local conditions. Besides, the fact that this specimen was a young individual could bias the inference on its feeding behaviour. For this reason, although we present the results of the RW analysis derived from the cranial anatomy of this fossil specimen, we urge readers to interpret them with caution.

The absence of a complete phylogenetic tree for the subfamily Tremarctinae precludes us to derive strong conclusions about the evolutionary patterns experimented by these bears in South America after the GABI. However, interestingly, we observe that the percentage of plant matter in their diets was increasing and this fact is most probably related to the increased diversity of other members of the large canivore guild of South America and their subsequent specialization. This fact strongly reflects the great evolutionary plasticity and adaptability of bears under changing environments and faunal interchange events.

Acknowledgements. - We are grateful to J. Galkin and C.A. Norris (Palaeontology Department, AMNH), E. Westwig (Mammalogy Department, AMNH), Louise Tomsset and Paula Jenkins (Mammalogy Department, NHMs), D. Webb (UF), A. Dondas (MMMP), D. Bo (MMPH), A. Reguero and L. Pomi (MLP), A. Kramarz (MACN) for kindly providing us access to the collections under their care. L.H.S. thank CONICET, ANPC y TPICT 38171 and Secretaría de Ciencia y Técnica de la UNLP for financial support. B.F. thanks the Ministerio de Educación y Ciencia for funding support under a $\mathrm{FPU} \mathrm{PhD}$ research grant and the research projects CGL2006-13808-C02-02 and CGL2008-04896. Paul Palmqvist and Juan A. Pérez-Claros contributed useful comments for developing this manuscript and provided insightful suggestions for improving an earlier version of the paper. We also acknowledge the comments of Francisco Prevosti and an anonymous reviewer, which greatly improved the rigour of the manuscript.

\section{References}

Adams, D.C., Rohlf, J.F. \& Slice, D.E. 2004: Geometric morphometrics: ten years of progress following the 'revolution'. Italian Journal of Zoology 71, 5-16.

Barone, R. 1986. Anatomie Compare des Mammiferes Domestiques: Ostéologie, Volume 1, 3rd edn, 761 pp. Vigot, Paris.

Biknevicius, A. \& Van Valkenburgh, B. 1996: Design for killing: craniodental adaptations of predators. In Gittleman, J.L. (ed.): Carnivores; Behavior, Ecology and Evolution, Volume 2, 393-428. Cornell University Press, Ithaca.

Bocherens, H., Emslie, S.D., Billiou, D. \& Mariotti, A. 1995: Stable isotopes $\left({ }^{13} \mathrm{C},{ }^{15} \mathrm{~N}\right)$ and palaeodiet of the giant short-faced bear (Arctodus simus). Comptes Rendus de l'Académie des sciences de Paris Serie II 320, 779-784.

Bookstein, F.L. 1991: Morphometric Tools for Landmarks Data. Geometry and Biology, 460 pp. Cambridge University Press, Cambridge.

Christiansen, P. 2005: Bite forces, canine strength and skull allometry in carnivores. Journal of Zoology 266, 133-151.
Christiansen, P. 2007: Evolutionary implications of bite mechanics and feeding ecology in bears. Journal of Zoology (London) 272, 423-443.

Christiansen, P. 2008: Feeding ecology and morphology of the upper canines in bears (carnivora: Ursidae). Journal of Morphology 269, 896-908.

Davis, D.D. 1955: Masticatory apparatus in the spectacled bear Tremarctos ornatus. Fieldiana: Zoology 37, 1-22.

Davis, D.D. 1964: The giant panda-a morphological study of evolutionary mechanisms. Fieldiana: Zoology Memoir Series 3, $1-339$.

DeMaster, D.P. \& Stirling, I. 1981: Ursus maritimus. Mammalian Species 145, 1-7.

Emslie, S.D. \& Czaplewski, N.J. 1985: A new record of the giant short-faced bear, Arctodus simus, from western North America with a reevaluation of its paleobiology. Natural History Museum of Los Angeles County Contributions in Science 371, 1-12.

Ewer, R.F. 1973: The Carnivores, 494 pp. Cornell University Press, New York.

Fariña, R.A. 1996: Trophic relationship among Lujanian mammals. Evolutionary Theory 11, 125-134.

Figueirido, B., Palmqvist, P. \& Pérez-Claros, J.A. 2009: Ecomorphological correlates of craniodental variation in bears and palaeobiological implications for extinct taxa: an approach based on geometric morphometrics. Journal of Zoology 277, 70-80.

Fitzgerald, C.S. \& Krausman, P.R. 2002: Helarctos malayanus. Mammalian Species 696, 1-5.

Gobetz, K.G. \& Martin, L.D. 2001: An exceptionally large shortfaced bear (Arctodus simus) from the Late Pleistocene/Early Holocene of Kansas. Current Research in the Pleistocene 18, 9799.

Joshi, R., Garshelis, D.L. \& Smith, J.L.D. 1997: Seasonal and habitat-related diets of sloth bears in Nepal. Journal of Mammalogy $78,584-597$.

Kragievlich, J.L. \& Olazabal, A.G. 1959: Los prociónidos extinguidos del género Chapadmalania Ameghino. Revista del Museo Argentino de Ciencias Naturales (Ciencias Zoológicas) 6, 1-59.

Krause, J., Unger, T., Noçon, A., Malaspinas, A., Kolokotronis, S., Stiller, M., Soibelzon, L., Spriggs, H., Dear, P.H., Briggs, A.W., Bray, S.C.E., O’Brien, S.J., Rabeder, G., Matheus, P., Cooper, A., Slatkin, M., Pääbo, S. \& Hofreiter, M. 2008: Mitochondrial genomes reveal an explosive radiation of extinct and extant bears near the Miocene-Pliocene boundary. BMC Evolutionary Biology 8,220 .

Krieguer, J. 2006: Measure LMs v4. Morpho-tools web site: <http:// www.morpho-tools.net>.

Kurtén, B. 1966: Pleistocene bears of North America. I. Genus Tremarctos, spectacled bears. Acta Zoologica Fennica 115, 1-120.

Kurtén, B. 1967: Pleistocene bears of North America, II: genus Arctodus, short-faced bears. Acta Zoologica Fennica 117, 1-60.

Kurtén, B. \& Anderson, E. 1980: Pleistocene Mammals of North America, 442 pp. Columbia University Press, New York.

Marugán-Lobón, J. \& Buscalioni, A.D. 2006: Avian skull morphological evolution: exploring exo- and endocranial covariation with two-block partial least squares. Zoology 109, 217-230.

Matheus, P.E. 1995: Diet and co-ecology of Pleistocene short-faced bears and brown bears in eastern Beringia. Quaternary Research $44,447-453$.

Mattson, D.J. 1998: Diet and morphology of extant and recently extinct northern bears. Ursus 10, 479-496.

McLellan, B. \& Reiner, D.C. 1994: A review of bear evolution. International Conference in Bear Research and Management 9, 85-96.

Palmqvist, P., Torregrosa, V., Pérez-Claros, J.A., Martínez-Navarro, B. \& Turner, A. 2007: A re-evaluation of the diversity of Megantereon (Mammalia, Carnivora, Machairodontinae) and the problem of species identification in extinct carnivores. Journal of Vertebrate Palaeontology 27, 160-175.

Pasitschniak-Arts, M. 1993: Ursus arctos. Mammalian Species 439, $1-10$.

Pelton, M.R. 1993: The American black bear. In Stirling, I. (ed.): Bears: Majestic Creatures of the Wild, 108-115. Rodale Press, Pennsylvania. 
Peyton, B. 1980: Ecology, distribution, and food habits of spectacled bears, Tremarctos ornatus, in Peru. Journal of Mammalogy 61, 639-652.

Prevosti, F.J. \& Vizcaíno, S.F. 2006: Palaeoecology of the large carnivore guild from the late Pleistocene of Argentina. Acta Palaeontologica Polonica 51, 407-422.

Reid, D.G. 1993: The Asiatic black bear. In Stirling, I. (ed.): Bears: Majestic Creatures of the Wild, 118-123. Rodale Press, Pennsylvania.

Richards, R.L. \& Tumbull, W.D. 1995: Giant short-faced bear (Arctodus simus yukonensis) remains from Fulton County, Northern Indiana. Fieldiana: New Series 30, 1-34.

Rohlf, F.J. 1993: Relative warp analysis and an example of its application to mosquito wings. In Marcus, L.F., Bello, E. \& GarcíaValdecasas, A. (eds): Contributions to Morphometrics, 131-159. Museo Nacional de Ciencias Naturales, Madrid.

Rohlf, F.J. 2006a: TpsDig, ver. 2.05. Department of Ecology and Evolution, State University of New York at Stony Brook, Stony Brook.

Rohlf, F.J. 2006b: TpsRelw, ver. 1.44. Department of Ecology and Evolution, State University of New York at Stony Brook, Stony Brook.

Sacco, T. \& Van Valkenburgh, B. 2004: Ecomorphological indicators of feeding behaviour in the bears (Carnivora: Ursidae). Journal of Zoology (London) 263, 41-54.

Schaller, G.B., Qitao, T., Johnson, K.G., Wang, X., Shen, H. \& Hu, J. 1989: The feeding ecology of giant pandas and Asiatic black bears in the Tangjiahe Reserve, China. In Gittleman, J.L. (ed.): Carnivore Behaviour, Ecology, and Evolution, Volume 1, 212-241. Cornell University Press, Ithaca.

Sillero-Zubiri, C., Hoffmann, M. \& Macdonald, D.W. 2004: Canids: Foxes, Wolves, Jackals and Dogs. Status Survey and Conservation Action Plan, 430 pp. IUCN Species Programme, Cambridge.

Slater, J.G. \& Van Valkenburgh, B. 2008: Long in the tooth: evolution of sabertooth cat cranial shape. Palaeobiology 34, 403419.

Soibelzon, L.H. 2002: Los Ursidae (Carnivora, Fissipedia) fósiles de la República Argentina. Aspectos Sistemáticos y Palaeoecológicos. Unpublished PhD thesis, 239 pp. Universidad Nacional de La Plata.
Soibelzon, L.H. 2004: Revisión sistemática de los Tremarctinae (Carnivora, Ursidae) fósiles de América del Sur. Revista del Museo Argentino de Ciencias Naturales 6, 105-131.

Soibelzon, L.H. \& Prevosti, F. 2007: Los carnívoros (Carnivora, Mammalia) terrestres del Cuaternario de América del Sur. In Pons, G.X. \& Vicens, D. (eds): Geomorfología Litoral i Quaternari. Homenatge a Joan Cuerda Barceló, 49-68, Monografia de la Societat d'Història Natural, Palma de Mallorca.

Soibelzon, L.H., Tonni, E.P. \& Bond, M. 2005: The fossil record of the South American short-faced bears (Ursidae, Tremarctinae). Journal of South American Earth Sciences 20, 105-113.

Soibelzon, L.H., Pomi, L.M., Tonni, E.P., Rodriguez, S. \& Dondas, A. 2009: First report of a short-faced bears' den (Arctotherium angustidens). Palaeobiological and palaeoecological implications. Alcheringa, doi: 10.1080/03115510902844418.

Sorkin, B. 2006: Ecomorphology of the giant short faced bears Agriotherium and Arctodus. Historical Biology 18, 1-20.

Stehli, F.G. \& Webb, S.D. 1985: The Great American Biotic Interchange, 550 pp. Plenum Press, New York.

Tedford, R.H. \& Martin, J. 2001: Plionarctos, a tremarctine bear (Ursidae: Carnivora) from western North America. Journal of Vertebrate Palaeontology 21, 311-321.

Thenius, E. 1959: Ursidenphyloyenese und biostratigraphie $Z$. Saugetierk 2, 78-84.

Thenius, E. 1976: Zur stammesgeschichtlichen Herkunft von Tremarctos (Ursidae, Mammalia) Z. Saugetierk 41, 109-114.

Trajano, H. \& Ferrarezzi, F. 1994: A Fossil Bear from Northeastern Brazil, with a phylogenetic Analysis of the South American Extinct Tremarctinae (Ursidae). Journal of Vertebrate Palaeontology 14, 552561.

Turnbull, W.D. 1970: Mammalian masticatory apparatus. Fieldiana: Geology 18, 152-356.

Van Valkenburgh, B. \& Ruff, C.B. 1987: Canine tooth strength and killing behavior in large carnivores. Journal of Zoology 212, 379397.

Vizcaíno, S.F. \& Bargo, M.S. 1998: The masticatory apparatus of the armadillo Eutatus (Mammalia, Cingulata) and some allied genera; palaeobiology and evolution. Palaeobiology 24, 371-383.

Webb, S.D. 1991: Ecogeography and the Great American Interchange. Palaeobiology 17, 266-280. 